\title{
Fire blight protection with avirulent mutants of Erwinia amylovora
}

\author{
Michel Tharaud, ${ }^{1}$ Jacqueline Laurent, ${ }^{2}+$ Mohamed Faize $^{1}$ \\ and Jean-Pierre Paulin ${ }^{3}$
}

Author for correspondence: Michel Tharaud. Tel: +332412254 38. Fax: +33241225459 .

1 ENSH-ENITHP, Laboratoire de Pathologie Végétale, 2 rue Le Notre, F-49045 Angers, France

2 Laboratoire de Pathologie Végétale, INRA, 16, rue Claude Bernard, F-75231 Paris Cedex 05, France

3 Station de Pathologie Végétale, INRA, Beaucouze, F-49070 Angers, France

\begin{abstract}
Fire blight is a necrotic disease caused by the bacterium Erwinia amylovora, which affects pears, apples and ornamentals including Crataegus, Pyracantha, and Cotoneaster. The disease can be only partially controlled, through the use of resistant genotypes, cultural measures and antibacterial compounds, thus other methods must be investigated. It has long been established that avirulent isolates of the pathogen can control the disease, under experimental conditions. However, field use of avirulent isolates is not acceptable because of their unknown genetic stability. The protective ability under controlled conditions of genetically characterized avirulent insertion mutants of $E$. amylovora was examined. A bioassay on apple seedlings was used for the determination of the protective ability of $\mathbf{3 4}$ insertion mutants (hrp, dsp, ams). Some protective effect could be observed with most of the mutants tested and was dependent on the avirulent/virulent inoculum ratio as well as on the level of virulence of the pathogen; a minimal concentration of the avirulent mutant was necessary to give a significant level of protection. An early competition between avirulent and virulent strains for putative infection sites might be involved. For six of the mutants tested, the protective ability was particularly high and might be related to the alteration of regulatory functions of $h r p$ genes. Results obtained with Ams' and Ams- Hrp- mutants suggested that the bacterial exopolysaccharide might play a role in the protection.
\end{abstract}

Keywords: Erwinia amylovora, biocontrol, avirulent mutants

\section{INTRODUCTION}

Fire blight caused by the bacterium Erwinia amylovora is a necrotic disease of economic importance which affects pear and apple trees as well as a range of ornamentals including Crataegus, Cotoneaster and Pyracantha (Aldwinckle \& Beer, 1979). The disease can be only partially controlled through the use of resistant plant genotypes, cultural measures, or applications of antibacterial compounds (streptomycin, copper and flumequine). Streptomycin, however, is banned for agricultural use in many countries, and resistance of bacteria to this antibiotic is becoming more widespread (Moller et al., 1981; Loper et al., 1991); copper compounds are often phytotoxic, and flumequine is expensive. Therefore, alternative control methods must

†Present address: Biologie Cellulaire, Université Paris-Sud, Bat. 444, F-91405 Orsay Cedex, France. be investigated. For this purpose, biological control of fire blight using microbial antagonists is considered a viable alternative to chemical control.

A number of biological agents have been tested against E. amylovora (Aldwinckle \& Beer, 1979). The epiphytic bacteria Erwinia herbicola and Pseudomonas fluorescens have been used extensively and were effective in controlling fire blight in pear or apple experimental orchards (Thomson et al., 1976; Beer et al., 1987; Kearns \& Hale, 1993) or of ornamentals (Isenbeck \& Schulz, 1985; Wilson et al., 1992a, b). Avirulent strains of $E$. amylovora also appeared to protect pear or apple tissues against fire blight infection under experimental conditions (Goodman, 1967; McIntyre et al., 1973; Wrather et al., 1973; Paulin, 1978). Nevertheless, they were not evaluated as potential biocontrol agents in any field studies. They could be valuable candidates if such strains, though avirulent, retained their ability to survive in their environment. In this respect they could be introduced successfully to compete with the pathogen. 
However, such a use is not ecologically acceptable, because the genetic stability of the avirulent strains is unknown. In contrast, avirulent insertion mutants, genotypically well characterized, might provide acceptably modified bacteria, as recently reported (Frey et al., 1994) for the biocontrol of tomato bacterial wilt.

Transposon insertions have produced two groups of avirulent mutants of E. amylovora. In one group the insertions appeared to map in a large $h r p$ region essential for both the elicitation of the hypersensitive reaction (HR) on non-host plants and pathogenicity on host plants (Steinberger \& Beer, 1988; Barny et al., 1990; Bauer \& Beer, 1991; Tharaud et al., 1994b). Some mutations in a part of this large cluster led to a loss of pathogenicity and a variable HR (Barny et al., 1990; Bauer \& Beer, 1991). This subregion was first designated as a $d s p$ (disease specific) region (Barny et al., 1990), and subsequently as a $\mathrm{hrm}$ (hypersensitive response modulator) region (Tharaud et al., 1994b). In another group of avirulent mutants the insertions mapped in an ams (amylovoran synthesis) region (Belleman \& Geider, 1992; Tharaud et al., 1994b). These mutants appeared to lack exopolysaccharide (mainly amylovoran) production.

In this paper, we report on the protective ability against fire blight of a collection of available avirulent mutants of E. amylovora, under controlled conditions. This collection of mutants consisted of 34 MudIIPR13 or Tn3Gus insertion mutants, phenotypically and genotypically characterized. Factors modulating the protection process were examined and the potential mechanisms are proposed. In previous reports (Tharaud et al., 1993, 1994a) we gave preliminary results of the protective ability of a few avirulent mutants as well as data on population dynamics in protective and non-protective situations.

\section{METHODS}

Bacterial strains and culture conditions. Bacterial strains used in this study are listed in Table 1 . Avirulent mutants as well as the localization of the MudIIPR13 and Tn3Gus insertional sites are described elsewhere (Barny et al., 1990; Menggad, 1994; Tharaud et al., 1994b). When available, restriction maps (Bauer \& Beer, 1991; Wei \& Beer, 1993, 1995) and published sequences (Wei \& Beer, 1993, 1995) of specific brp genes were used to define more precisely the location of a mutational insertion. The double mutant strain PMV6076-D4 was obtained by marker-exchange mutagenesis of the $b r p-d s p$ mutant PMV6076 (Barny et al., 1990) with the plasmid pEA109-4 (Bernhard et al., 1993). CFBP1376, a naturally avirulent isolate which exhibited a high protective ability in preliminary experiments (Tharaud et al., 1994a) was used as a positive control. Bacteria were routinely grown for $24 \mathrm{~h}$ at $27^{\circ} \mathrm{C}$ on King's medium B (KB; King et al., 1954), supplemented with chloramphenicol $\left(10 \mu \mathrm{g} \mathrm{ml}^{-1}\right)$ for the MudIIPR13 mutants, or kanamycin $\left(20 \mu \mathrm{g} \mathrm{ml}^{-1}\right)$ for the Tn3Gus and Tn5 mutants.

Plant material and growth conditions. Actively growing young (five to eight leaves) apple seedlings from openpollinated cv 'Golden Delicious' were grown in 0.31 pots containing a commercial soil mix (sand $1 / 3$, peat $1 / 3$, soil $1 / 3)$. The experiments were conducted in a greenhouse $\left(20^{\circ} \mathrm{C}\right.$, $80 \%$ relative humidity, natural photoperiod) especially designed to prevent release of potentially harmful bacteria into the environment.

Plant inoculation. The youngest expanded leaf of each plant was wounded by a double incision $(\sim 1 \mathrm{~mm})$ perpendicular to the midrib, approximately in the middle of the leaf. One drop $(10 \mu \mathrm{l})$ of bacterial suspension was immediately placed on the wound. Two types of inoculations were used: (i) sequential inoculation, in which the avirulent (potentially protective) strain was applied on the wound $2 \mathrm{~h}$ before the virulent strain; and (ii) co-inoculation, in which suspensions of the avirulent and the virulent strains were mixed in a test tube immediately before laying one drop of the mixture on the wound. Sterile water was used as a control. Ten plants $(20$ in some experiments) were inoculated with each mutant for each procedure of inoculation (sequential inoculation or co-inoculation). In most cases each experiment was repeated at least twice at different times.

In our standard assay for protective ability, the bacterial suspensions were adjusted in sterile water as follows: avirulent strains $3 \times 10^{9}$ c.f.u. $\mathrm{ml}^{-1}$ (i.e. $3 \times 10^{7}$ c.f.u. applied per plant), and virulent strain $3 \times 10^{8}$ c.f.u. $\mathrm{ml}^{-1}$ (i.e. $3 \times 10^{6}$ c.f.u. applied per plant). The inoculum concentration was evaluated by plating serial dilutions onto KB. The influence of the inoculum concentration was studied by the use of sequential inoculations for four avirulent strains (PMV6046, PMV6070, PMV6075 and CFBP1376) versus the virulent CFBP1430. Avirulent/virulent inoculum concentrations were as follows (c.f.u. per plant): $3 \times 10^{5} / 3 \times 10^{4}, 3 \times 10^{5} / 3 \times 10^{5}, 3 \times 10^{6} /$ $3 \times 10^{5}, 3 \times 10^{6} / 3 \times 10^{6}, 3 \times 10^{7} / 3 \times 10^{6}, 3 \times 10^{7} / 3 \times 10^{7}$.

The protective effect of three avirulent strains (PMV6046, PMV6075 and CFBP1376) against the following virulent strains of E. amylovora was tested: CFBP3049, CFBP3050, CFBP3051 and CFBP1430 (from the most to the least virulent, according to the frequency of infections and mean length of necrosis after inoculation on apple genotypes; Paulin et al., 1993).

Assessment of results. The extent of the symptoms (necrosis on the midrib of the inoculated leaves, then on petiole and stem) was noted for 3 weeks after inoculation. A plant was considered protected when at the end of this period no necrosis could be noticed on the stem or petiole. A necrosis limited to the leaf blade, without progression in the petiole, was considered as protection. The protective ability of an avirulent strain was assessed by the percentage of infected plants (i.e. non protected) as compared to the percentage obtained with the water control. For each strain these percentages of infected plants were compared by Fisher's exact test.

\section{RESULTS}

\section{Protective ability of the avirulent mutants}

In these experiments the virulent strain was CFBP1430, which is the standard strain of the pathogen used in our inoculation tests for resistance to fire blight and from which the avirulent insertion mutants were derived. The percentages of infected plants calculated 3 weeks after inoculation are shown in Table 2 . When the virulent CFBP1430 was inoculated alone (water protection 
Table 1. Bacterial strains

\begin{tabular}{|c|c|c|}
\hline Strain & $\begin{array}{l}\text { Relevant characteristics, altered gene } \\
\text { and/or complementation group }\end{array}$ & Reference \\
\hline CFBP1430 & Virulent isolate from Crataegus sp. & Paulin \& Samson (1973) \\
\hline CFBP3049 & Virulent isolate from apple (CUCPB070) & Norelli et al. (1984) \\
\hline CFBP3050 & Virulent isolate from apple (CUCPB071) & Norelli et al. (1984) \\
\hline CFBP3051 & Virulent isolate from apple (CUCPB273) & Norelli et al. (1984) \\
\hline CFBP1376 & Avirulent isolate from Cotoneaster sp., $b r p L, \mathrm{~V}$ & $\begin{array}{l}\text { Bauer \& Beer (1991); Paulin \& Samson } \\
\text { (1973); Wei \& Beer (1995) }\end{array}$ \\
\hline PMV6023 & hrp-23:: MudIIPR13, $\mathrm{Cm}^{\mathrm{r}}, \mathrm{VI}$ & Barny et al. (1990); Wei \& Beer (1993) \\
\hline PMV6024 & $h r p-24::$ MudIIPR 13, $\mathrm{Cm}^{\mathrm{r}}, h r p L, \mathrm{~V}$ & Barny et al. (1990); Wei \& Beer (1995) \\
\hline PMV6033 & hrp-33::MudIIPR13, $\mathrm{Cm}^{\mathrm{r}}, \mathrm{IV}$ & Barny et al. (1990); Wei \& Beer (1993) \\
\hline PMV6041 & $d s p-41::$ MudIIPR $13, \mathrm{Cm}^{\mathrm{r}}$ & Barny et al. (1990) \\
\hline PMV6043 & hrp-43:: MudIIPR 13, $\mathrm{Cm}^{\mathrm{r}}, \mathrm{VI}$ & Barny et al. (1990); Wei \& Beer (1993) \\
\hline PMV6044 & hrp-44::MudIIPR13, $\mathrm{Cm}^{\mathrm{r}}, \mathrm{II}$ & Barny et al. (1990); Wei \& Beer (1993) \\
\hline PMV6045 & hrp-45::MudIIPR 13, $\mathrm{Cm}^{\mathrm{r}}$, III & Barny et al. (1990); Wei \& Beer (1993) \\
\hline PMV6046 & hrp-46: : MudIIPR 13, $\mathrm{Cm}^{\mathrm{r}}, \mathrm{IV}$ & Barny et al. (1990); Wei \& Beer (1993) \\
\hline PMV6047 & $d s p-47::$ MudIIPR $13, \mathrm{Cm}^{\mathrm{r}}$ & Barny et al. (1990) \\
\hline PMV6059 & $d s p-59::$ MudIIPR13, $\mathrm{Cm}^{\mathrm{r}}$ & Barny et al. (1990) \\
\hline PMV6069 & $d s p-69::$ MudIIPR 13, $\mathrm{Cm}^{\mathrm{r}}$ & Barny et al. (1990) \\
\hline PMV6070 & dsp-70::MudIIPR13, $\mathrm{Cm}^{\mathrm{r}}$ & Barny et al. (1990) \\
\hline PMV6073 & brp-73:: MudIIPR13, $\mathrm{Cm}^{\mathrm{r}}, \mathrm{IV}$ & Barny et al. (1990); Wei \& Beer (1993) \\
\hline PMV6074 & hrp-74::MudIIPR13, $\mathrm{Cm}^{\mathrm{r}}, \operatorname{brpL}, \mathrm{V}$ & Barny et al. (1990); Wei \& Beer (1995) \\
\hline PMV6075 & hrp-75::MudIIPR13, $\mathrm{Cm}^{\mathrm{r}}$, VI & Barny et al. (1990); Wei \& Beer (1993) \\
\hline PMV6076 & $\Delta(b r p, d s p)::$ MudIIPR $13, \mathrm{Cm}^{\mathrm{r}}$ & Barny et al. (1990) \\
\hline PMV6076-D4 & $\begin{array}{l}\Delta(h r p, d s p):: \text { MudIIPR } 13 \\
\text { amsE::Tn } 5, \mathrm{Cm}^{\mathrm{r}} \mathrm{Km}^{\mathrm{r}} \\
\text { non-capsulated }\end{array}$ & This work \\
\hline PMV6077 & hrp-77:: MudIIPR13, $\mathrm{Cm}^{\mathrm{r}}$, III & Barny et al. (1990); Wei \& Beer (1993) \\
\hline PMV6079 & dsp-79: : MudIIPR 13, $\mathrm{Cm}^{\mathrm{r}}$ & Barny et al. (1990) \\
\hline PMV6081 & hrp-81:: MudIIPR13, $\mathrm{Cm}^{\mathrm{r}}$, III & Tharaud et al. (1994b); Wei \& Beer (1993) \\
\hline PMV6082 & $\Delta(h r p, d s p)::$ MudIIPR $13, \mathrm{Cm}^{\mathrm{r}}$ & Tharaud et al. (1994b) \\
\hline PMV6084 & hrp-84:: MudIIPR 13, Cm ${ }^{\mathrm{r}}, \mathrm{VI}$ & Barny et al. (1990); Wei \& Beer (1993) \\
\hline PMV6086 & hrp-86: : MudIIPR 13, $\mathrm{Cm}^{\mathrm{r}}$, VI & Tharaud et al. (1994b); Wei \& Beer (1993) \\
\hline PMV6087 & $\begin{array}{l}\text { hrp-87: : MudIIPR } 13, \mathrm{Cm}^{\mathrm{r}} \\
\text { not precisely localized }\end{array}$ & Tharaud et al. (1994b) \\
\hline PMV6088 & hrp-88::MudIIPR13, $\mathrm{Cm}^{\mathrm{r}}, \mathrm{VI}$ & Tharaud et al. (1994b); Wei \& Beer (1993) \\
\hline PMV6089 & $\begin{array}{l}\text { ams-89: : MudIIPR } 13, \mathrm{Cm}^{\mathrm{r}} \\
\text { non-capsulated, amsI }\end{array}$ & $\begin{array}{l}\text { Bugert \& Geider (1995); Menggad (1994); } \\
\text { Tharaud et al. (1994b) }\end{array}$ \\
\hline PMV6096 & $d s p-96::$ MudIIPR $13, \mathrm{Cm}^{\mathrm{r}}$ & Tharaud et al. (1994b) \\
\hline PMV6101 & $\Delta(d s p)::$ MudIIPR $13, \mathrm{Cm}^{\mathrm{r}}$ & Tharaud et al. (1994b) \\
\hline PMV6102 & $\Delta(d s p)::$ MudIIPR $13, \mathrm{Cm}^{\mathrm{r}}$ & Tharaud et al. (1994b) \\
\hline PMV6114 & hrp-114:: MudIIPR13, $\mathrm{Cm}^{\mathrm{r}}$, III & Tharaud et al. (1994b); Wei \& Beer (1993) \\
\hline PMV6115 & $d s p-115::$ MudIIPR13, $\mathrm{Cm}^{\mathrm{r}}$ & Tharaud et al. (1994b) \\
\hline PMV6117 & hrp-117::MudIIPR13, Cm ${ }^{\mathrm{r}}$, VIII & Tharaud et al. (1994b); Wei \& Beer (1993) \\
\hline PMV6119 & hrp-119::MudIIPR 13, $\mathrm{Cm}^{\mathrm{r}}$, II & Tharaud et al. (1994b); Wei \& Beer (1993) \\
\hline PMV6193 & $\begin{array}{l}\text { ams-193:: Tn } 3 \mathrm{Gus}, \mathrm{Km}^{\mathrm{r}} \\
\text { non-capsulated, amsI }\end{array}$ & Bugert \& Geider (1995); Menggad (1994) \\
\hline
\end{tabular}

CFBP, Collection Française de Bactéries Phytopathogènes; CUCPB, Cornell University Collection of Phytopathogenic Bacteria; PMV, Pathologie Moléculaire et Végétale (Laboratoire de Pathologie Végétale, INRA, Paris).

control) the percentage of infected plants was always high : $86 \pm 4 \cdot 2 \%$ (standard error; sequential inoculation) or $90 \pm 5.7 \%$ (co-inoculation) of the plants showed necrosis on the stem or on the petiole.
With sequential inoculation, the percentage of infected plants was significantly reduced by the previous inoculation of 25 out of the 32 tested avirulent mutants, as well as that of the avirulent strain CFBP1376. For most 
Table 2. Protective ability of the avirulent mutants

Apple seedlings were inoculated with the avirulent mutants (or the avirulent strain CFBP1376) $\left(3 \times 10^{7}\right.$ c.f.u. per plant) or water, $2 \mathrm{~h}$ before (sequential inoculation) or in the same time as (coinoculation) the virulent strain CFBP1430 $\left(3 \times 10^{6}\right.$ c.f.u. per plant); 10 plants (20 in some experiments) were inoculated with each mutant. The results are shown as the percentage of infected plants (those exhibiting necrosis on stem or petiole within 3 weeks of inoculation) from one experiment (1) or means of several (number in parentheses) experiments. Results in bold type are means which are significantly different from the water control according to Fisher's exact test $(5 \%)$ in each experiment.

\begin{tabular}{|c|c|c|c|}
\hline \multirow[t]{2}{*}{ Mutant } & \multirow{2}{*}{$\begin{array}{c}\text { Gene and/or } \\
\text { complementation group }\end{array}$} & \multicolumn{2}{|c|}{ Percentage of infected plants } \\
\hline & & $\begin{array}{l}\text { Sequential } \\
\text { inoculation }\end{array}$ & Co-inoculation \\
\hline Water & (Control) & $86(8)$ & $90(4)$ \\
\hline \multicolumn{4}{|l|}{ Dsp $^{-}$mutants } \\
\hline PMV6041 & ND & $16(3)$ & $90(2)$ \\
\hline PMV6047 & ND & $15(2)$ & $90(1)$ \\
\hline PMV6059 & ND & $6.5(3)$ & $70(2)$ \\
\hline PMV6069 & ND & $3.5(3)$ & $60(1)$ \\
\hline PMV6070 & ND & $\mathbf{0}(2)$ & $75(2)$ \\
\hline PMV6079 & ND & $10(1)$ & $55(2)$ \\
\hline PMV6096 & ND & $0(1)$ & $50(1)$ \\
\hline PMV6115 & ND & $20(1)$ & $60(2)$ \\
\hline \multicolumn{4}{|l|}{ Hrp $^{-}$mutants } \\
\hline PMV6101 & $\Delta d s p$ & NT & $77 \cdot 5(3)$ \\
\hline PMV6102 & $\Delta d s p$ & NT & $76.5(2)$ \\
\hline PMV6076 & $\Delta(h r p, d s p)$ & $\mathbf{0}(2)$ & $30(2)$ \\
\hline PMV6082 & $\Delta(h r p, d s p)$ & $0(2)$ & $16 \cdot 5(2)$ \\
\hline PMV6044 & II & $10(2)$ & $45(2)$ \\
\hline PMV6119 & II & $0(1)$ & $90(1)$ \\
\hline PMV6045 & III & $20(1)$ & $60(1)$ \\
\hline PMV6077 & III & $30(2)$ & $60(1)$ \\
\hline PMV6081 & III & $25(2)$ & $90(1)$ \\
\hline PMV6114 & III & $20(2)$ & $80(1)$ \\
\hline PMV6033 & IV & $0(1)$ & $25 \cdot 5(2)$ \\
\hline PMV6046 & IV & $0(3)$ & $12.5(4)$ \\
\hline PMV6073 & IV & $3 \cdot 5(3)$ & $6.5(3)$ \\
\hline CFBP1376 & $h r p L, \mathrm{~V}$ & $3.5(8)$ & $15(4)$ \\
\hline PMV6024 & $h r p L, \mathrm{~V}$ & $10(1)$ & $14 \cdot 5(2)$ \\
\hline PMV6074 & $b r p L, \mathrm{~V}$ & $10(2)$ & $60(2)$ \\
\hline PMV6023 & VI & $\mathbf{0}(1)$ & $40(1)$ \\
\hline PMV6043 & VI & $10(3)$ & $85(2)$ \\
\hline PMV6075 & $\mathrm{VI}$ & $15(5)$ & $80(2)$ \\
\hline PMV6084 & VI & $20(1)$ & $40(1)$ \\
\hline PMV6086 & VI & $30(2)$ & $90(1)$ \\
\hline PMV6088 & VI & $10(1)$ & $40(1)$ \\
\hline PMV6117 & VIII & $30(2)$ & $90(1)$ \\
\hline PMV6087 & Not localized & $30(2)$ & $70(2)$ \\
\hline \multicolumn{4}{|l|}{ Ams- mutants } \\
\hline PMV6089 & $a m s I$ & $60(4)$ & $68(3)$ \\
\hline PMV6193 & $a m s I$ & $63(3)$ & $67(3)$ \\
\hline \multicolumn{4}{|c|}{ Hrp $^{-}$Ams $^{-}$mutant } \\
\hline PMV6076-D4 & $\Delta(b r p, d s p), a m s E$ & $70(2)$ & $80(2)$ \\
\hline
\end{tabular}

ND, Not determined; NT, not tested. 
CFBP1376 PMV6046 $\$ PMV6070 目PMV6075 $\square$ Water (control)

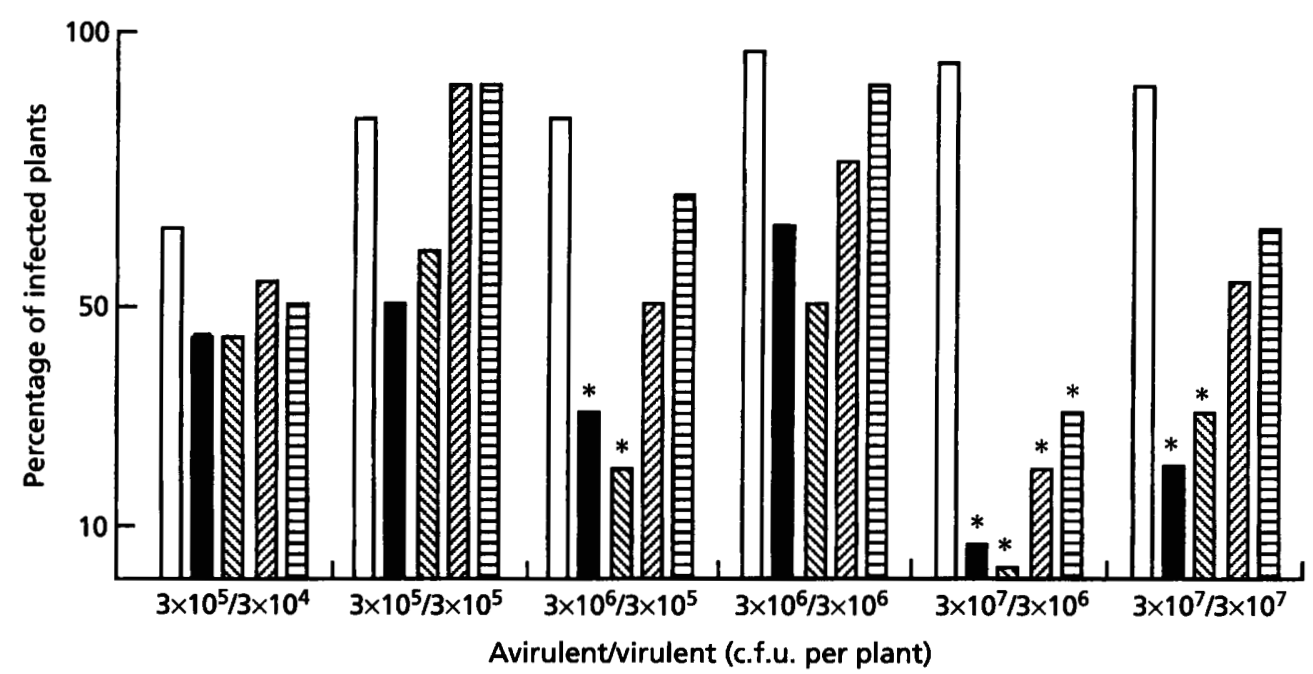

Fig. 1. Influence of inoculum concentration and avirulent/virulent ratio on the protective effect of selected strains. Ten apple seedlings were inoculated with avirulent mutants (PMV6046, PMV6070, PMV6075) or the avirulent strain CFBP1376, or water control, $2 \mathrm{~h}$ before inoculation with the virulent strain CFBP1430. The results are means of two experiments. Means which are significantly different from the water control according to Fisher's exact test (5\%) in both experiments are marked with an asterisk.

mutants (15 out of 25) and for CFBP1376 this effect was repeatedly observed. With mutants PMV6077, PMV6086, PMV6087 and PMV6117 the protective effect was only occasionally observed. With PMV6089, PMV6193 and PMV6076-D4 the percentage of infected plants was high in all experiments (mean value $60 \%$, $63 \%$ and $70 \%$, respectively), which indicated a lack of protection by these mutants.

With co-inoculation, only 7 strains out of 35 tested were able to reduce significantly the percentage of infected plants, indicating a protective effect against fire blight. Two strains were mutated in brpL (CFBP1376 and PMV6024); three mutations were located in complementation group IV (strains PMV6033, PMV6046 and PMV6073); the two other protective strains, PMV6076 and PMV6082, were deleted of the entire hrp cluster (Table 1).

Protected plants never showed any subsequent necrosis when examined after more than 3 weeks (data not shown). Furthermore, when the virulent CFBP1430 strain was inoculated $\left(3 \times 10^{6}\right.$ or $3 \times 10^{4}$ c.f.u. per plant) $2 \mathrm{~h}$ or $0.5 \mathrm{~h}$ before an avirulent protective strain $\left(3 \times 10^{7}\right.$ c.f.u. per plant), no control effect was ever observed (data not shown).

\section{Influence of the inoculum concentration}

Four avirulent strains, PMV6046 (complementation group IV), PMV6070 (Dsp-), PMV6075 (complementation group VI) and CFBP1376 ( $\left.\mathrm{HrpL}^{-}\right)$and the virulent CFBP1430 were tested using the sequential inoculation procedure with various inoculum concentrations and different avirulent/virulent ratios. Results are given in Fig. 1. For these four avirulent strains a significant reduction in the percentage of infected plants was noticed in each experiment when inoculum concentrations were 'standard', i.e. (c.f.u. per plant) avirulent strain $3 \times 10^{7}$, virulent strain $3 \times 10^{6}$, giving an avirulent/virulent ratio of $10: 1$. Both PMV6046 and CFBP1376 still significantly reduced the percentage of infected plants when avirulent to virulent cell concentrations (c.f.u. per plant) of $3 \times 10^{6} / 3 \times 10^{5}(10: 1)$ and $3 \times 10^{7} / 3 \times 10^{7}(1: 1)$ were applied. In all other situations studied (the other two avirulent mutants, and other inoculum concentrations giving ratios of $10: 1$ or $1: 1$ ), no significant protective effect was noticed.

\section{Influence of the virulence level of the pathogen}

The protective effect of three avirulent strains against four virulent wild-type strains was tested with both the sequential inoculation and co-inoculation procedures (Table 3). With the sequential inoculation procedure, whatever the virulence of the challenger strain, PMV6046 and CFBP1376 showed a protective effect, unlike PMV6075, which was only effective against the least virulent strains, CFBP3051 and CFBP1430. With the co-inoculation procedure, PMV6046 and CFBP1376 offered protection only against the least virulent strains CFBP3051 and CFBP1430. The mutant PMV6075 was not effective in these co-inoculation experiments. 
Table 3. Influence of the virulence level of the pathogen on the protective effect induced by avirulent mutants

\begin{tabular}{|c|c|c|c|c|}
\hline \multirow[t]{2}{*}{ Avirulent mutant } & \multicolumn{4}{|c|}{ Pathogenic strain*: } \\
\hline & \multicolumn{4}{|c|}{ CFBP3049 CFBP3050 CFBP3051 CFBP1430 } \\
\hline & \multicolumn{4}{|c|}{$\begin{array}{l}\text { Percentage of infected plants with } \\
\text { sequential inoculation procedure }\end{array}$} \\
\hline Water (control) & 95 & 95 & 95 & 95 \\
\hline PMV6046 & 20 & 10 & $\mathbf{0}$ & $\mathbf{5}$ \\
\hline PMV6075 & 70 & NT & 20 & 20 \\
\hline \multirow{2}{*}{$\begin{array}{l}\text { Avirulent strain } \\
\text { CFBP1376 }\end{array}$} & 5 & $\mathbf{0}$ & $\mathbf{0}$ & $\mathbf{0}$ \\
\hline & \multicolumn{4}{|c|}{$\begin{array}{l}\text { Percentage of infected plants with } \\
\text { co-inoculation procedure } \neq\end{array}$} \\
\hline Water (control) & $100(2)$ & $100(1)$ & $100(1)$ & $100(2)$ \\
\hline PMV6046 & $90(2)$ & $90(1)$ & $40(1)$ & $25(2)$ \\
\hline PMV6075 & $100(1)$ & $90(1)$ & $75(1)$ & $80(1)$ \\
\hline $\begin{array}{l}\text { Avirulent strain } \\
\text { CFBP1376 }\end{array}$ & $60(2)$ & $70(1)$ & $20(1)$ & $25(2)$ \\
\hline
\end{tabular}

*From the most to the least virulent: CFBP3049, CFBP3050, CFBP3051, CFBP1430.

†Ten apple seedlings were inoculated with the avirulent mutants (or the avirulent strain CFBP1376) $\left(3 \times 10^{7}\right.$ c.f.u. per plant) or water $2 \mathrm{~h}$ before the virulent strains $\left(3 \times 10^{6}\right.$ c.f.u. per plant $)$; results are the means of two experiments. Results in bold type are means which are significantly different from the water control according to Fisher's exact test $(5 \%)$ in each experiment. NT, Not tested.

¥Twenty apple seedlings were inoculated with the avirulent mutants (or the avirulent strain CFBP1376) $\left(3 \times 10^{7}\right.$ c.f.u. per plant) or water mixed with the virulent strains $\left(3 \times 10^{6}\right.$ c.f.u. per plant). The results are either the percentage of infected plants from one experiment (1), or means of two experiments (2). Results in bold type are means which are significantly different from the water control according to Fisher's exact test $(5 \%)$ in each experiment.

\section{DISCUSSION}

In this paper we have shown that several avirulent mutant strains of E. amylovora are able to prevent apple seedlings from developing fire blight symptoms when inoculated before or simultaneously with a virulent strain. As emphasized by the high level of disease observed with the water controls, the protective effect was obtained even under conditions highly favourable to fire blight development.

The method of inoculation appeared questionable when we had to design the experimental procedure for evaluating the protective ability of avirulent strains. The wounding of a leaf, which is a widely used procedure, might have interfered with the results due to woundinduced defence response of the plant (Bostock \& Stermer, 1989; Matta, 1991; Bradley et al., 1992). Thus, we attempted to develop an inoculation procedure without wounding: spraying a suspension of the virulent strain led to a high infection rate only under saturated relative humidity applied for several hours to apple seedlings, making such a virulence assay system difficult for examining a large number of strains. The experimental procedure we chose by-passes the first steps of the pathogen penetration into the plant. Nevertheless the results showed that, once the pathogen was inside the plant tissues, it was possible to clearly discriminate between pathogenicity and protection, confirming the validity of the inoculation method.

In well-defined experimental conditions, the protective effect was quite reproducible. Several parameters, however, proved to play a role in the occurrence and/or in the level of protection : the type of avirulent mutant, the type of virulent strain, the timing of inoculation of the avirulent and virulent strains, and the absolute and relative concentrations of the avirulent and virulent strains. Different types of behaviour in terms of protection of different avirulent mutants were revealed according to the other parameters; the correlation with altered functions will be discussed.

Most avirulent mutants were regularly able to protect apple seedlings against fire blight infection in sequential inoculation experiments in which the avirulent mutant was inoculated $2 \mathrm{~h}$ before inoculating the virulent strain. Only three strains, PMV6089 (Ams'), PMV 6193 (Ams ${ }^{-}$), and PMV6076-D4 ( $\mathrm{Hrp}^{-} \mathrm{Ams}^{-}$), were unable to do so. Conversely, six $\mathrm{Hrp}^{-}$strains showed a highly protective effect, exhibiting a significant protective ability even in co-inoculation experiments. These highly protective strains, however, were unable to protect apple seedlings when applied after the virulent strain within a $2 \mathrm{~h}$ or even a $0.5 \mathrm{~h}$ delay.

Four avirulent protective strains were used, with the sequential inoculation procedure, to study the influence of the inoculum concentrations and avirulent/virulent ratios. In the main our results are consistent with previous studies which indicated that the avirulent/ virulent ratio should be at least $10: 1$ to obtain a significant protective effect against fire blight (Goodman, 1967; Paulin, 1978), bacterial wilt of tobacco and tomato (Averre \& Kelman, 1964; Trigalet \& TrigaletDémery, 1990), and crown gall (Lippincott \& Lippincott, 1969). In addition we showed that a minimal concentration of the avirulent strain, $3 \times 10^{7}$ c.f.u. per plant for basic protective strains, was required to give a significant level of protection. Moreover, the different protective avirulent mutants exhibited different characteristics in this regard, since highly protective strains were able to protect as soon as their inoculum concentration reached $3 \times 10^{6}$ c.f.u. per plant together with a 10:1 avirulent/virulent ratio. They were even protective at a $1: 1$ ratio with a $3 \times 10^{7}$ c.f.u. per plant inoculum.

Another approach which discriminated between the highly protective mutants and the others was the protection that they developed towards different virulent isolates, in the sequential inoculation procedure. However, even the highly protective strains PMV6046 and CFBP1376 were not protective when the plants were co- 
inoculated with the more virulent wild-type isolates CFBP3049 and CFBP3050. There is presently no satisfactory hypothesis to account for different levels of virulence in E. amylovora. One can assume that, the more virulent a strain is, the earlier the pathogenesis functions are triggered and/or the more intensely they are expressed. In such cases this would make it more difficult for protection to take place, whatever the mechanisms involved.

Altogether our data indicated that events taking place very close to the time of inoculation might determine the issue of the plant-pathogen interaction, suggesting that protection or disease would result from an early competition between avirulent and virulent bacteria. Competition for nutrients is unlikely, however, since no protective effect was observed when the virulent strain was inoculated before the avirulent strain. Competition for putative infection sites of the host plant is more likely, as suggested by the data from the inoculum concentration experiments. A recognition step between the virulent strain and the host plant would be required to start the infectious process. Data from Hignett (1987, 1988) and Cooper et al. (1990) previously suggested that a contact between host plant cells and E. amylovora seemed necessary for pathogenicity. If that is the case, prior occupation by an avirulent mutant could prevent the virulent strain from reaching the infection sites, which in turn would explain the protection in the sequential inoculation procedure as well as the effective inoculum concentrations. Since the Ams ${ }^{-}$mutants were never effective in protecting the host plant in these conditions, it is suggested that amylovoran might play a role in the recognition process and, consequently, in protection. This role would be primordial since the highly protective mutant PMV6076 ( $\Delta h r p)$ lost its protective ability when secondarily mutated in an ams gene.

However, the higher protection exhibited by some avirulent strains could hardly be explained in such a context. The three characteristics of highly protective strains are: ability to protect against CFBP1430 in the co-inoculation procedure, ability to protect in conditions of lower inoculum concentration, and ability to protect against the most virulent wild-type strains in sequential inoculation. Furthermore, these highly protective mutants are either (i) deleted of the entire $b r p-d s p$ genomic region (PMV6076, PMV6082), or (ii) altered in the $b r p L$ gene (PMV6024 and CFBP1376) or in one gene located at one end of complementation group IV, possibly hrpS (PMV6033, PMV6046 and PMV6073). These genes appeared to be involved in regulatory functions (Wei \& Beer, 1995; Bogdanove et al., 1996). This suggests that the highly protective effect is due to the alteration of one of these regulatory functions.

Our previous results dealing with population dynamic studies (Tharaud et al., 1993, 1994a) showed that, whatever the protecting mutant, when there was protection, the population of the virulent strain decreased to a very low level; when there was no protection, the virulent strain multiplied after a delay. Since competition for nutrients is unlikely, these data led us to hypothesize that a plant response is possibly involved in the phenomenon of protection.

All these observations are consistent with the central role assigned to brp genes in the plant-bacteria interaction (Willis et al., 1991; Clarke et al., 1992; Gough et al., 1992). We are currently investigating the possible role of the host plant in protection. Considering the numerous failures reported in biocontrol attempts against plant pathogens, such studies are now urgently needed to provide better understanding of the mechanisms involved in the biocontrol and therefore to allow its use with reasonable chances of success.

\section{ACKNOWLEDGEMENTS}

This work was supported in part by grants from EPR pays de la Loire and DGER of French Ministry of Agriculture. We thank Dr M. N. Brisset and Dr J. Hartman for their critical reading of the manuscript. We are grateful to $\mathrm{R}$. Chartier, G. Lachaud and M. Thomas for helpful technical assistance, and to $M$. Travers for typing of the manuscript.

\section{REFERENCES}

Aldwinckle, H. S. \& Beer S. V. (1979). Fire blight and its control. Hortic Rev 1, 423-475.

Averre, C. W. \& Kelman, A. (1964). Severity of bacterial wilt as influenced by ratio of virulent to avirulent cells of Pseudomonas solanacearum in inoculum. Phytopathology 54, 779-783.

Barny, M.-A., Guinebretière, M.-H., Marçais, B., Coissac, E., Paulin, J.-P. \& Laurent, J. (1990). Cloning of a large gene cluster involved in Erwinia amylovora CFBP1430 virulence. Mol Microbiol 4, 777-786.

Bauer, D. W. \& Beer, S. V. (1991). Further characterization of an hrp gene cluster of Erwinia amylovora. Mol Plant-Microbe Interact 4, 493-499.

Beer, S. V., Rundle, J. R. \& Norelli, J. (1987). Orchard evaluation of five strains of Erwinia berbicola for control of blossom infection. Acta Hortic 217, 219 (abstract).

Belleman, P. \& Geider, K. (1992). Localization of transposon insertions in pathogenicity mutants of Erwinia amylovora and their biochemical characterization. J Gen Microbiol 138, 931-940.

Bernhard, F., Coplin, D. L. \& Geider, K. (1993). A gene cluster for amylovoran synthesis in Erwinia amylovora: characterization and relationship to cps genes in Erwinia stewartii. Mol Gen Genet 239,158-168.

Bogdanove, A. J., Wei, Z.-M., Zhao, L. \& Beer, S. V. (1996). Erwinia amylovora secretes harpin via a type III pathway and contains a homolog of yopN of Yersinia spp. J Bacteriol 178, 1720-1730.

Bostock, R. M. \& Stermer, B. A. (1989). Perspectives on wound healing in resistance to pathogens. Annu Rev Phytopathol 27, 343-371.

Bradley, D. J., Kjellbom, P. \& Lamb, C. J. (1992). Elicitor- and wound-induced oxidative cross-linking of a proline-rich plant cell wall protein: a novel, rapid defense response. Cell 70, 21-30.

Bugert, P. \& Geider, K. (1995). Molecular analysis of the ams operon required for exopolysaccharide synthesis of Erwinia amylovora. Mol Microbiol 15, 917-933. 
Clarke, H. R. G., Leigh, J. A. \& Douglas, C. J. (1992). Molecular signals in the interactions between plants and microbes. Cell 71, 91-99.

Cooper, R. M., Youle, D., Katerinas, A. \& Fox, C. (1990). Host induced virulence in Erwinia amylovora. Acta Hortic 273, 267-274.

Frey, P., Prior, P., Marie, C., Kotoujansky, A., Trigalet-Démery, D. \& Trigalet, A. (1994). Hrp ${ }^{-}$mutants of Pseudomonas solanacearum as potential biocontrol agents of tomato bacterial wilt. Appl Environ Microbiol 60, 3175-3181.

Goodman, R. N. (1967). Protection of apple stem tissue against Erwinia amylovora infection by avirulent strains and three other bacterial species. Phytopathology 57, 22-24.

Gough, C. L., Genin, S., Zischek, C. \& Boucher, C. A. (1992). brp genes of Pseudomonas solanacearum are homologous to pathogenicity determinants of animal pathogenic bacteria and are conserved among plant pathogenic bacteria. Mol Plant-Microbe Interact 5, 348-389.

Hignett, R. C. (1987). Inhibition of fireblight disease by injection of D-galactose or L-fucose into susceptible apple plants. Physiol Mol Plant Pathol 30, 131-138.

Hignett, R. C. (1988). Effects of growth conditions on the surface structures and extracellular products of virulent and avirulent forms of Erwina amylovora. Physiol Mol Plant Pathol 32, 387-394.

Isenbeck, M. \& Schulz, F. A. (1985). Biological control of fire blight (Erwinia amylovora (Burr.) Winslow et al.) on ornamentals. 1. Control of the pathogen by antagonistic bacteria. Phytopathol $Z$ 113, 324-333.

Kearns, L. P. \& Hale, C. N. (1993). Biological control of fire blight by Erwinia herbicola: survival of applied bacteria in orchard and glasshouse trials. Acta Hortic 338, 333.

King, E. O., Ward, M. K. \& Raney, D. E. (1954). Two simple media for the demonstration of pyocyanin and fluorescein. J Lab Clin Med 44, 301-307.

Lippincott, B. B. \& Lippincott, J. A. (1969). Bacterial attachment to a specific wound site as an essential stage in tumor initiation by Agrobacterium tumefaciens. J Bacteriol 97, 620-628.

Loper, J. E., Henkels, M. D., Roberts, R. G., Grove, G. G., Willet, M. J. \& Smith, T. J. (1991). Evaluation of streptomycin, oxytetracycline, and copper resistance of Erwinia amylovora isolated from pear orchards in Washington State. Plant Dis 75, 287-290.

Matta, A. (1991). The role of cell injury in induced resistance. Petria 1, 85-98.

McIntyre, J. L., Kuc, J. \& Williams, E. B. (1973). Protection of pear against fire blight by bacteria and bacterial sonicates. Phytopathology 63, 872-877.

Menggad, M. (1994). Etude génétique et moléculaire de la région chromosomique ams impliquée dans le pouvoir pathogène et la production de l'exopolysaccharide acide de la capsule d'Erwinia amylovora. Thèse de Docteur en Sciences, Université de Paris XI, Orsay, France.

Moller, W. J., Schroth, M. N. \& Thomson, S. V. (1981). The scenario of fire blight and streptomycin resistance. Plant Dis $\mathbf{6 5}$, $563-568$.

Norelli, J. L., Aldwinckle, H. S. \& Beer, S. V. (1984). Differential host-pathogen interactions among cultivars of apple and strains of Erwinia amylovora. Phytopathology 74, 136-139.
Paulin, J.-P. (1978). Biological control of fireblight: preliminary experiments. In Proceedings of the 4th International Conference on Plant Pathogenic Bacteria, Angers, France, p. 525. Angers: Station de Pathologie Végétale et Phytobactériologie.

Paulin, J.-P. \& Samson, R. (1973). Le feu bactérien en France.II. Caractères des souches d'Erwinia amylovora (Burrill) Winslow et al., 1920, isolées du foyer franco-belge. Ann Phytopathol 5, 389-397.

Paulin, J.-P., Lachaud, G. \& Lespinasse, Y. (1993). Role of the agressiveness of strains of Erwinia amylovora in the experimental evaluation of susceptibility of apple cultivars to fire blight. Acta Hortic 338, 375-376 (abstract).

Steinberger, E. M. \& Beer, S. V. (1988). Creation and complementation of pathogenicity mutants of Erwinia amylovora. Mol Plant-Microbe Interact 1, 135-144.

Tharaud, M., Baudouin, E. \& Paulin, J.-P. (1993). Protection against fire blight by avirulent strains of Erwinia amylovora: modulation of the interaction by avirulent mutants. Acta Hortic 338, 321-327.

Tharaud, M., Baudouin, E. \& Paulin, J.-P. (1994a). Protection against fire blight by an avirulent strain of Erwinia amylovora: possible role of the host in the interaction. In Plant Pathogenic Bacteria, pp. 943-949. Edited by M. Lemattre, S. Freigoun, K. Rudolph \& J. G. Swings. Paris: INRA (Les Colloques, no. 66). Tharaud, M., Menggad, M., Paulin, J.-P. \& Laurent, J. (1994b). Virulence, growth, and surface characteristics of Erwinia amylovora mutants with altered pathogenicity. Microbiology 140 , 659-669.

Thomson, S. V., Schroth, M. N., Moller, W. J. \& Reil, W. O. (1976). Efficacy of bactericides and saprophytic bacteria in reducing colonization and infection of pear flowers by Erwinia amylovora. Phytopathology 66, 1457-1459.

Trigalet, A. \& Trigalet-Démery, D. (1990). Use of avirulent mutants of Pseudomonas solanacearum for the biological control of bacterial wilt of tomato plants. Physiol Mol Plant Pathol 36, 27-38.

Wei, Z.-M. \& Beer, S. V. (1993). HrpL of Erwinia amylovora functions in secretion of harpin and is a member of a new protein family. J Bacteriol 175, 7958-7967.

Wei, Z.-M. \& Beer, S. V. (1995). hrpL activates Erwinia amylovora hrp gene transcription and is a member of the ECF subfamily of $\sigma$ factors. J Bacteriol 177, 6201-6210.

Willis, D. K., Rich, J. J. \& Hrabak, E. M. (1991). hrp genes of phytopathogenic bacteria. Mol Plant-Microbe Interact 4, 132-138.

Wilson, M., Epton, H. A. S. \& Sigee, D. C. (1992a). Biological control of fire blight of hawthorn (Crataegus monogyna) with fluorescent Pseudomonas spp. under protected conditions. Phytopathology 136, 6-26.

Wilson, M., Epton, H. A. S. \& Sigee, D. C. (1992b). Interactions between Erwinia herbicola and E. amylovora on the stigma of hawthorn blossoms. Phytopathology 82, 914-918.

Wrather, J. A., Kuc, J. \& Williams, E. B. (1973). Protection of apple and pear fruit tissue against fireblight with nonpathogenic bacteria. Phytopathology 63, 1075-1076.

Received 4 July 1996; revised 20 September 1996; accepted 26 September 1996. 